Article

\title{
The 'GartenApp': Assessing and Communicating the Ecological Potential of Private Gardens
}

\author{
Anne-Katrin Schneider ${ }^{1, *}$, Michael W. Strohbach ${ }^{1}$, Mario App ${ }^{1,2}$ and Boris Schröder 1,3 (D) \\ 1 Landscape Ecology and Environmental Systems Analysis, Institute of Geoecology, \\ Technische Universität Braunschweig, 38106 Braunschweig, Germany; m.strohbach@tu-braunschweig.de \\ 2 Institute of Biodiversity, Johann Heinrich von Thünen-Institute, 38116 Braunschweig, Germany; \\ mario.app@tu-braunschweig.de \\ 3 Berlin-Brandenburg Institute of Advanced Biodiversity Research, 14195 Berlin, Germany; \\ boris.schroeder@tu-braunschweig.de \\ * Correspondence: anne-kathrin.schneider@tu-braunschweig.de; Tel.: +49-531-3915954
}

Received: 31 October 2019; Accepted: 20 December 2019; Published: 21 December 2019

check for updates

\begin{abstract}
Private gardens make up large parts of urban green space. In contrast to public green spaces, planning and management is usually uncoordinated and independent of municipal planning and management strategies. Therefore, the potential for private gardens to provide ecosystem services and habitat and to function as corridors for wildlife is not fully utilized. In order to improve public knowledge on gardens, as well as provide individual gardeners with information on what they can contribute to enhance ecosystem services provision, we developed a GIS-based web application for the city of Braunschweig (Germany): the 'GartenApp' (garden app). Users of the app have to outline their garden on a web map and provide information on biodiversity related features and management practices. Finally, they are asked about observations of well recognizable species in their gardens. As an output, the gardeners are provided with an estimate of the ecosystem services their garden provides, with an evaluation of the biodiversity friendliness, customized advice on improving ecosystem services provision, and results from connectivity models that show gardeners the role of their garden in the green network of the city. In this paper, we describe the app architecture and show the first results from its application. We finish with a discussion on the potential of GIS-based web applications for urban sustainability, planning and conservation.
\end{abstract}

Keywords: green infrastructure; urban; ecosystem services; connectivity modelling; citizen science

\section{Introduction}

Urban green spaces (UGSs) can provide numerous ecosystem services that support the climate change resilience of cities, such as carbon storage in trees [1], cooling effects by evapotranspiration and shading [2,3] or flood protection by unsealed areas [4]. In addition, UGSs fulfill manifold recreational aspects for residents [5], support public health [6] and are key areas for people to experience wild plants and animals, engaging them in environmental conservation [7]. Large UGSs resemble islands in an urban matrix and can be biodiversity hotspots [8,9]. Other UGS elements, such as smaller parks, road verges, street trees, and gardens, may function as habitat and also as corridors for urban biodiversity [10-14]. To emphasize that not only the quantity but also the spatial configuration and connectivity of UGSs is important for functionality, the term 'green infrastructure' (GI) has been introduced [15].

Private gardens can make up a significant proportion of urban green space in cities [16,17], and therefore have an important role in the urban ecosystem $[12,14,18,19]$. Their ability to provide ecosystem services and habitat is scale dependent, however, and a certain size and quality is 
needed $[3,11,20,21]$. Single gardens are usually too small to have an effect and gardeners would need to coordinate design and management. Decisions on their management and design are being made on the individual level, however, often resulting in what Odum referred to as the 'Tyranny of Small Decisions,' i.e., a degradation due to small-scale and uncoordinated management [13,22-24]. In addition, the awareness for the public value of individual gardens for contributing to GI appears to be low [25]. Even if there is awareness, garden practices are strongly driven by perceived norms and do not necessarily reflect the values of the garden owners [24,25]. Hence, no easy solution for increasing the public value of gardens in providing ecosystem services and contributing to biodiversity conservation exists, but social processes play a key role [24,25]. In keeping with the UN Sustainable Development Goal 11.3 [26] and the Habitat III New Urban Agenda [27], these approaches should be inclusive and participatory.

Approaches to overcome the 'Tyranny of Small Decisions' commonly build on providing gardeners with relevant information on their role in the urban ecosystem, empowering and encouraging them to contribute, and engaging them through citizens science $[13,22,24,28-30]$. The latter is also important for improving the evidence-based planning of GI. While remote sensing is also contributing valuable data, e.g., traditional vegetation indices such as NDVI [31], impervious surface [32], or vegetation heights [21], remote sensing is unlikely to be capable of detecting small biodiversity related features, such as the flower diversity of a lawn or the availability of nesting boxes or fences that exclude wildlife from moving between potentially suitable patches [30]. Thus, consideration of both garden surveys as well as remote sensing information could lead to a comprehensive assessment of individual garden management [30,31]. With current technology, assessments of gardens can easily and effectively be performed with web-based applications that can host simple questionnaires along with mapping tools [31]. Ideally, such a system would allow for direct feedback between gardeners, scientists and municipalities.

In this paper, we present a web-based GIS platform, the 'GartenApp' (garden app), which provides and collects information on gardens. Gardeners in the city of Braunschweig (Germany) draw their garden on a map and enter whether they provide certain biodiversity enhancing features and manage their garden in a biodiversity friendly way. We use this information, along with vegetation heights derived from remote sensing material, to calculate ecosystem service provisioning by the garden, focusing on carbon storage, cooling, shading, and biodiversity potential. In order to show gardeners the role of their garden for GI, we present them with results from connectivity models. The connectivity of urban green space depends on the focal species, and taking 3D effects (i.e., vegetation heights) into account is important $[14,21,33]$. Therefore, we chose two model species that are common in gardens and well-liked [34] and represent two vegetation layers: the European hedgehog (Erinaceus europaeus) as a ground dwelling species and the red squirrel (Sciurus vulgaris) as a tree dwelling species. In addition to describing the app architecture, we show the first results from 75 gardens, surveyed with the GartenApp. Platforms such as the GartenApp could be valuable tools that can easily be adapted to be used for communication and knowledge transfer between scientists, citizens, and municipalities.

\section{Materials and Methods}

\subsection{Study Area}

Braunschweig is located in the federal state of Lower Saxony in northern Germany $\left(52.264^{\circ} \mathrm{N}\right.$, $10.524^{\circ} \mathrm{E}$ ). The municipality covers $192 \mathrm{~km}^{2}$, the total population is 248,292 and the population density is $1288.5 \mathrm{~km}^{2}$ (31 December 2018; [35]). Average precipitation is $637 \mathrm{~mm}$, with monthly averages between 37 and $68 \mathrm{~mm}$, and the average temperature is $9.5^{\circ} \mathrm{C}$, with January being the coldest $\left(1.3^{\circ} \mathrm{C}\right)$ and July being the warmest $\left(18.3^{\circ} \mathrm{C}\right.$ ) month (averages for period of 1981-2010, station ID 662 from [36]). The climate is classified as $\mathrm{Cfb}$ (warm temperate, fully humid, warm summer; [37]). The city is located on the transition from the fertile loess soils of the uplands in the southwest to the poor sandy soils of the lowlands in the northeast [38]. Elevation ranges between 60 and $112 \mathrm{~m}$ (digital elevation model of 
Braunschweig from 2011). The city is located in the floodplain of the river Oker. The former old town is surrounded by a green ring of parks, gardens and alleys, clearly visible in the center of Figure 1. Also visible is the network of parks, meadows and lakes along the river Oker in the south and in the northwest of the green ring. Large forests and recreation areas can be found in the east, west and northeast of Braunschweig. The former old town was largely destroyed in World War II, but densely rebuilt since then and contains little green space. East and west of the green ring, dense tenement blocks from the Wilhelmine Period (second half of the 19th to 1918) are located, surrounded by less-dense multi-story housing from later periods. Otherwise, large parts of the city are single or semi-detached houses, including two garden cities from the National Socialist period (1933-1945) and several villages that are still partly surrounded by agricultural areas. In total, $8 \%\left(15.4 \mathrm{~km}^{2}\right)$ of the urban area is covered by urban green spaces (including sports fields and cemeteries), $11.2 \%\left(21.6 \mathrm{~km}^{2}\right)$ by forests and $36.5 \%$ $\left(70.1 \mathrm{~km}^{2}\right)$ by agricultural areas [39].

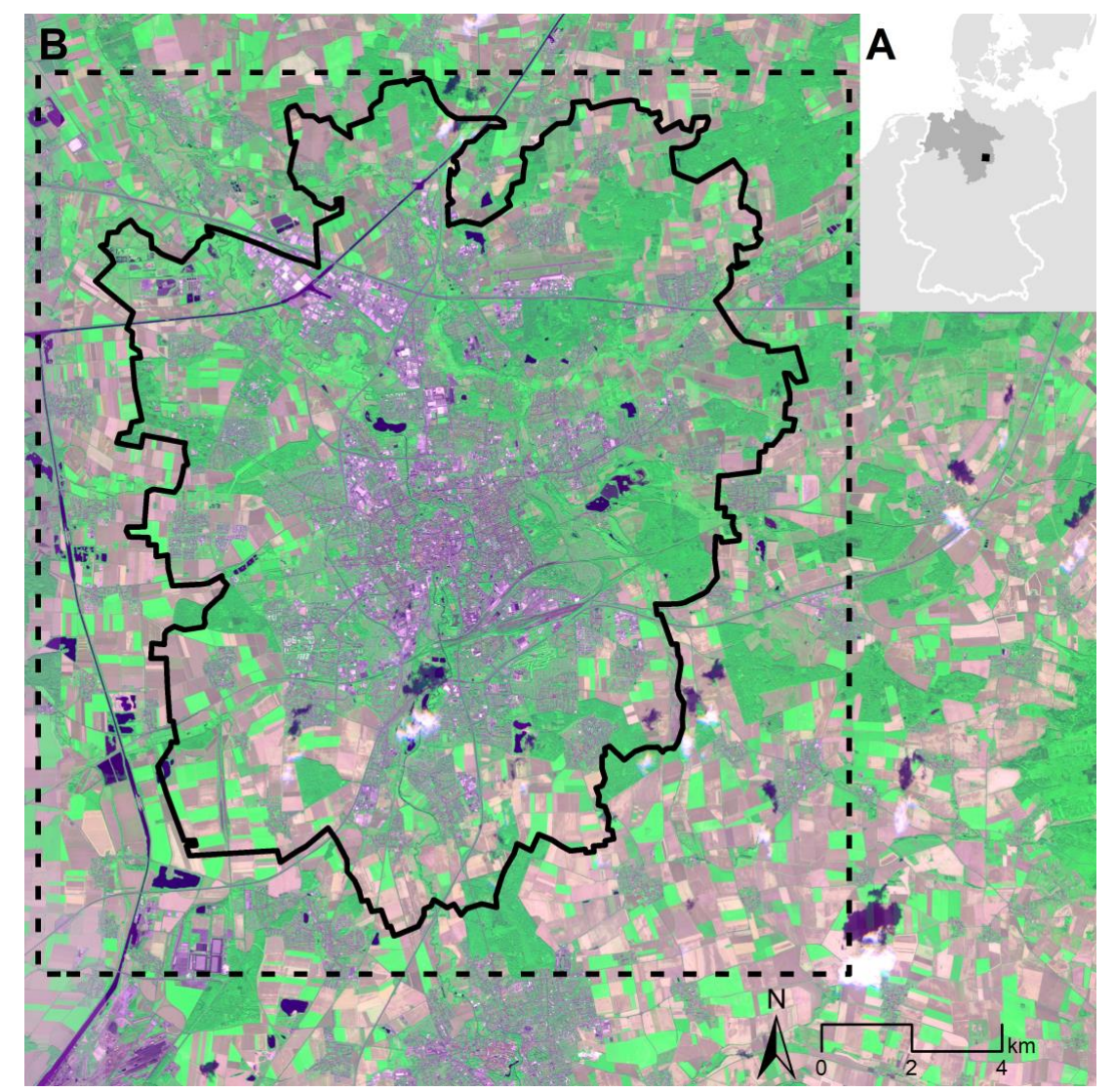

Figure 1. The location of Braunschweig (black square) in Germany (white line) and in the federal state of Lower Saxony (dark gray; (A)); and city of Braunschweig (black line) in a false-color satellite image highlighting vegetation (B). The GartenApp works within the dashed line. Data A: ESRI basemap Europe and [40]. Data B: RapidEye Science Archive Project-ID 00253; [40].

\subsection{Vegetation Heights}

In a first step, we classified an orthophoto mosaic with red, green, blue and infrared channels with a spatial resolution of $20 \mathrm{~cm}$ (Figure 2A), covering the bounding box of the municipal boundary (Figure 1; orthophoto mosaic from 18 May 2017; provided by the city of Braunschweig). We chose a classification into two classes - 'vegetation' and 'other' —and used a 'Random Forest' machine learning approach with 1200 manually created training points (implemented with the package randomForest [41] in $R$ (version 3.5.2; [42]). One-third of these points was used for validation and the classification error was less than $2 \%$. The Random Forest model was then used to classify the entire dataset (Figure 2B). 
In a second step, we created a $1 \mathrm{~m}$ resolution digital surface model (DSM) from LiDAR (laser scanning) data. Two LiDAR data sources were used. For the city of Braunschweig, a dataset with a resolution of 5 points per $\mathrm{m}^{2}$ and a height precision of $\pm 0.15 \mathrm{~m}$, obtained in the fall of 2011, was provided by the city of Braunschweig. For the areas within the bounding box, but outside of the municipal boundary, a dataset with a resolution of 3.5 points per $\mathrm{m}^{2}$ and a height precision of $\pm 0.15 \mathrm{~m}$, obtained in the spring of 2013, was provided by the regional planning authorities 'Regionalverband Braunschweig'. A digital terrain model (DTM; provided by the city of Braunschweig for areas within the municipal boundary, and interpolated from the LiDAR data for areas outside of the municipal boundary, using classified ground points and the Raster Interpolation toolbox in ArcGIS 10.6) was then subtracted from the DSM, in order to create net heights (Figure 2C). In a third step, the vegetation raster was resampled to a $1 \mathrm{~m}$ resolution and combined with the net heights. Finally, building footprints (from [43]) were subtracted in order to remove green roofs and tree canopy above buildings. In addition, vegetation below power lines (from [39]) was set to ground level, in order to remove artefacts from the power lines and poles (Figure 2D). All spatial analyses were carried out in ArcGIS 10.6.

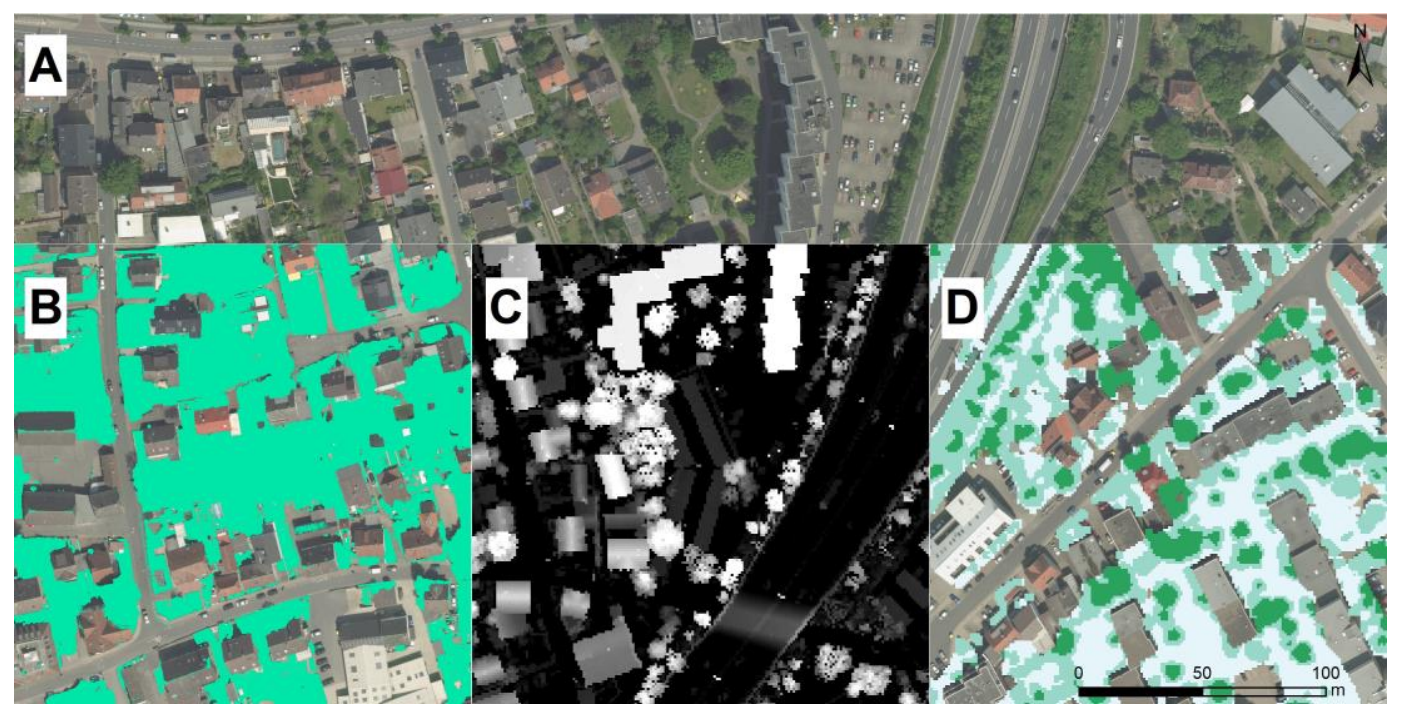

Figure 2. An overview on how vegetation heights were created: First, color infrared orthophotos (A) were classified into 'vegetation' and 'other' (B). The vegetation was then combined with net heights (C) to create a vegetation height layer (D).

\subsection{Connectivity Modelling}

We used the electric circuit theory based connectivity modelling software Circuitscape [44] to model connectivity maps for the European hedgehog as a ground dwelling species and the red squirrel as a tree dwelling species in Braunschweig. Circuitscape demands species-specific landscape resistance maps [44]. Relevant landscape elements were derived from vegetation height data (see Section 2.2) and cadaster data [39]. The maps had an extent of $18 \times 28 \mathrm{~km}^{2}$, with a resolution of $3 \mathrm{~m}$ for the squirrels $\left(\sim 40 \times 10^{6}\right.$ raster cells) and $16 \times 19 \mathrm{~km}^{2}$ with a resolution of $2 \mathrm{~m}$ for the hedgehogs $\left(\sim 75 \times 10^{6}\right.$ raster cells $)$. Resistance values for squirrels were parameterized according to [45] and for hedgehogs, according to [46] (see Tables A1 and A2, respectively, for parameterization). In case of hedgehogs, we extended or slightly modified the parameterization of [46]: We set the landscape resistance of allotment gardens and cemeteries to high permeability (i.e., $R=1 \Omega$ ), while railways were assumed to act as a barrier (i.e., $R=100 \Omega$ ) and the canal in the northwest of the city as an absolute barrier ( $\mathrm{R}=$ infinite). Publicly managed areas with grass and shrubs, as well as connected garden areas with a minimum of 1 ha, were set as core habitats. In the case of squirrels, we chose green spaces and forests of at least 10 ha as core habitats. These core areas were connected pairwise, choosing a maximum distance for hedgehogs of $1 \mathrm{~km}$, and for squirrels of $2 \mathrm{~km}$ (distances based on typical roaming behavior [45,46]). The pairwise 
current flow was combined into city wide current flow density maps (Figure 3). Raster cells with high current flow density (Ampere per cell) have a high importance for connectivity, low flow densities a low importance for connectivity. The maps can be intuitively interpreted by lay people [44].
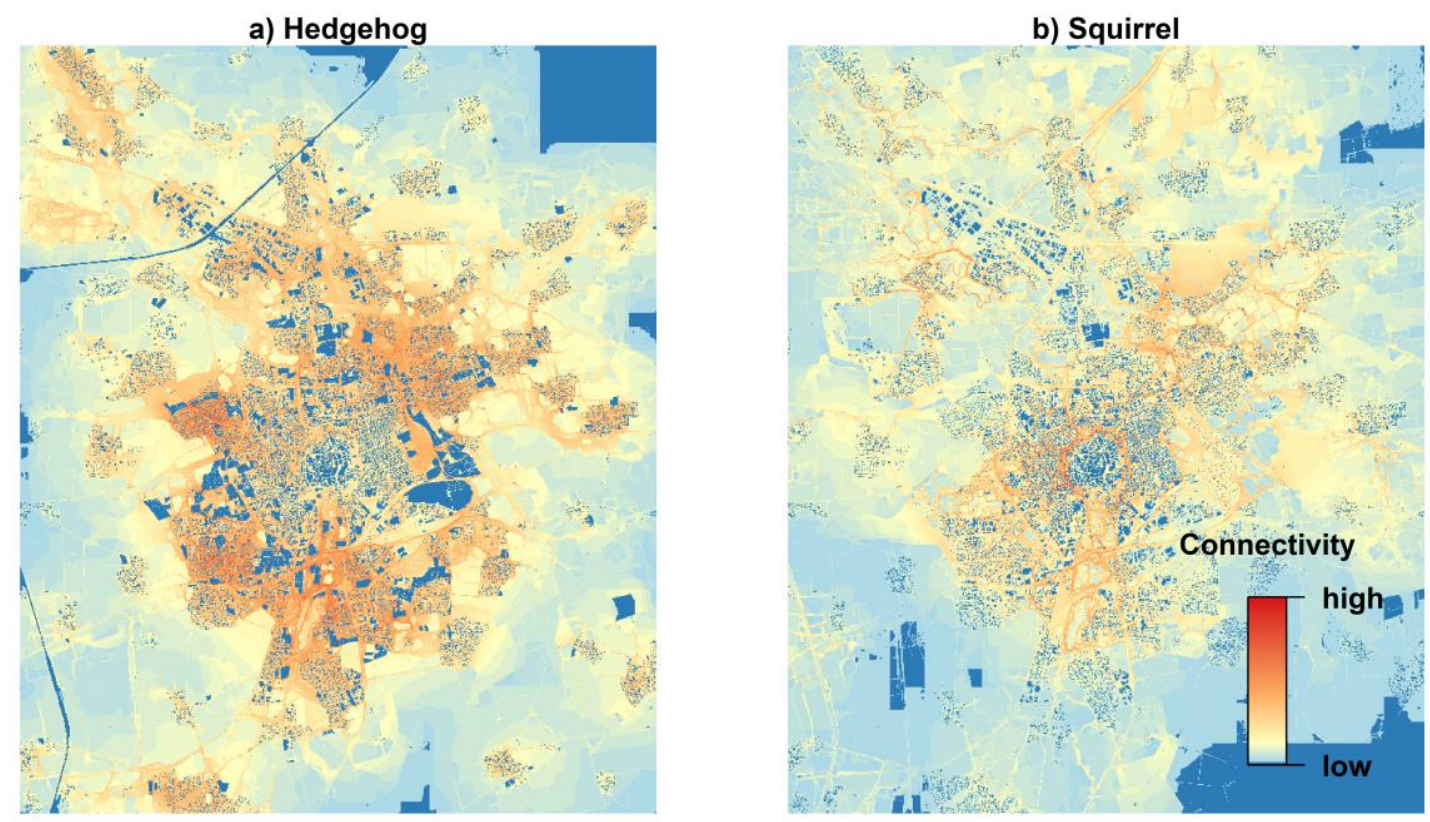

Figure 3. Current flow densities for (a) hedgehogs and (b) red squirrels. Current flow density is given as relative connectivity ranging between low and high, because absolute values are not comparable.

\subsection{App Architecture}

The GartenApp currently runs on two servers: (i.) a PostgreSQL 9.6 server with the PostGIS 2.3.3 extension is used for data storage, including the vegetation heights from Section 2.2 and current flow densities from 2.3; (ii.) a Shiny server v1.5.9.923 is used for hosting a RStudio Shiny app [47]. The app's frontend is divided into five main sections: (1) mapping the garden, (2) biodiversity questionnaire, (3) vegetation structure output, (4) ecosystem services assessment output, and (5) connectivity output. In the following, the individual sections are described in detail. Videos of the app in action are shown in Videos S1-S3.

\subsubsection{Mapping the Garden}

After some initial information on the app, gardeners are asked to draw a polygon around their garden. We used the Leaflet open-source JavaScript library for mobile-friendly interactive maps with the $\mathrm{R}$ package leaflet 2.0.1 [48]. The polygon is later used for a spatial query that loads vegetation height and current flow density data for the specific garden from the data base (using rpostgis 1.4.2 [49]), and for creating plots (see also Video S1).

\subsubsection{Questionnaire on the Biodiversity Potential of Gardens}

The biodiversity friendliness of garden management and design is assessed with 10 checkboxes that are based on peer-reviewed publications (Table 1). In addition, the biodiversity friendliness of lawn and planting beds is assessed, based on a recent study [50]. The user can select lawn, meadow, vegetable and flower plots that match sketches from [50] with radio buttons. 
Table 1. Ecological functions of biodiversity friendly features in gardens derived from a literature survey.

\begin{tabular}{|c|c|c|}
\hline Feature & Function & Reference \\
\hline Nesting box for birds & $\begin{array}{l}\text { increases species richness of birds; } \\
\text { an indirect effect can be an increase } \\
\text { in the number of bumblebee nests }\end{array}$ & {$[11,51]$} \\
\hline Bird feeder & $\begin{array}{l}\text { increased resource availability increases bird } \\
\text { density and occurrence of certain bird species }\end{array}$ & [52-54] \\
\hline Hedge & $\begin{array}{l}\text { provide nesting opportunities for bumblebees; } \\
\text { provision of shelter and litter for snails }\end{array}$ & {$[51,55]$} \\
\hline Compost heap & $\begin{array}{l}\text { increases number of bumblebee nests; } \\
\text { habitat for beetles, springtails and mites; } \\
\text { increases beetle and slug species richness }\end{array}$ & {$[51,55-57]$} \\
\hline Fruit trees and berry shrubs & $\begin{array}{l}\text { increases resource availability and habitat for birds and insects } \\
\text { (sugar-rich fruits as resource for garden-inhabiting species, } \\
\text { lipid-rich fruits for migrating species) }\end{array}$ & {$[58,59]$} \\
\hline Deadwood storage & increases presences of fungi and other saproxylic species & [57] \\
\hline Stone wall & $\begin{array}{l}\text { habitat for lizards, insects and xerophilous plants and lichens; } \\
\text { increases species richness of slugs, snails }\end{array}$ & {$[55,59]$} \\
\hline Wild patches & increase diversity and abundance of bees & [60] \\
\hline Nesting support for insects & increases survival probability of pollinators & [61] \\
\hline Ponds & $\begin{array}{l}\text { habitat for water plants, amphibians and insects; } \\
\text { watering place for birds; } \\
\text { increases presence of a broad range of wild } \\
\text { species (e.g., foxes, moles, snakes) }\end{array}$ & {$[57,59,62,63]$} \\
\hline
\end{tabular}

\subsubsection{Vegetation Structure of the Garden}

This section is the first results panel. The garden's vegetation structure is visualized as a bird's eye view on the garden. In order to simplify this, we present vegetation height in three classes: grass layer $(<0.5 \mathrm{~m})$, shrubs $(0.5-4 \mathrm{~m})$ and trees ( $>4 \mathrm{~m}$; classification according to [21]). We use this section to explain (i) how the data was generated and (ii) reasons for possible errors. For example, if trees have been removed since 2011, they would still appear in the visualization. Depending on the respective amount of the vegetation-height classes, the gardeners are provided with a custom text. Structurally diverse gardens (grass layer, shrubs and trees each cover more than 15\%) result in 'Well done, go on!'. If one class is lacking, we give simple recommendations such as 'Your garden is dominated by shrubs. A few trees and some grass/meadow patches can improve the vegetation structure of your garden!' (see also Video S3).

\subsubsection{Ecosystem Services Assessment}

Three ecosystem services that are closely related to vegetation are calculated and presented: carbon storage, cooling effects and shadowing. All three services are presented on a bar plot that spans 'low' (no vegetation in the garden) to 'high' (the whole garden is covered by trees). Carbon storage in tree stems was estimated according to empirical findings for single- and semidetached houses in the city of Leipzig (6.38 $\mathrm{kg} \mathrm{C} \mathrm{m}^{-2}$; [1]). Vegetation heights below $2 \mathrm{~m}$ were neglected.

The cooling effect of the vegetation was estimated similarly to [3,64], applying a linear regression between air temperature and vegetation volume. We used air temperature from a sensor network of 15 weather stations in Braunschweig (see [65]), measured in $3 \mathrm{~m}$ height above ground level (to keep the sensors safe from destruction). We selected air temperatures measured at 15:00 (usually the maximum air temperature) at five windless and cloudless summer days in 2017 (2 June, 31 July, and 7, 28 and 29 August). Vegetation volume was derived from vegetation heights (Section 2.2) over an 
area with $10 \mathrm{~m}$ radius around each of the 15 weather stations. We applied a linear mixed effects model with air temperature as response variable, vegetation volume as fixed effects predictor and the date as random effects variable (random intercept). In the GartenApp, the cooling potential for each garden is presented as a barplot of the relative cooling potential derived from the fixed effects estimate. We set the maximum or optimum reachable cooling effect $(100 \%)$ to a vegetation volume of $3000 \mathrm{~m}^{3}$ which corresponds to a $300 \mathrm{~m}^{2}$ garden completely covered by $10 \mathrm{~m}$ trees. For the assessment of the cooling potential, the intercept is neglected and only the slope of the regression line is used (this corresponds to the rate of temperature change, i.e., air temperature decreases by $0.6{ }^{\circ} \mathrm{C}$ when vegetation volume is increased by $1000 \mathrm{~m}^{3}$; Table 2). Hence, we yield a relative cooling potential for the garden, independent from the actual air temperature and only on the basis of the vegetation volume. All analyses were performed in $\mathrm{R}$ (version 3.5.2; [42]) with package nlme (version 3.1-137; [66]) for mixed effects model fitting.

Table 2. Estimated regression parameters from linear mixed effects model fitting. Random effects variance of 'date' is 4.18. Approximate $p$-values for estimated parameters are $\ll 0.05 . \chi^{2}$ test for fixed effect yielded a significant effect of incorporating 'Vegetation volume' in the model $\left(\chi^{2}=88, d . f .=1, p \ll 0.05\right)$. Marginal explained variance ('fixed effects only') is $R_{m}^{2}=0.14$ and conditional explained variance (fixed + random effects) is $R_{c}^{2}=0.84$.

\begin{tabular}{cccc}
\hline Parameter & Estimate & Standard Error & $t$-Value \\
\hline Intercept $\left[{ }^{\circ} \mathrm{C}\right]$ & 26.38 & 0.92 & 28.63 \\
Vegetation volume $\left[\mathrm{m}^{3}\right]$ & $-0.60 \times 10^{-3}$ & $6.38 \times 10^{-5}$ & -9.38 \\
\hline
\end{tabular}

Shading by vegetation is an effective way to reduce heat stress [67]. We calculated shading using the $\mathrm{R}$ package shadow 0.6 .0 [68]. It calculates shading by simple 3D objects, depending on spatial location and time of day. In order to simplify the vegetation, the following steps are taken: (i) We remove pixels with a height below $2 \mathrm{~m}$, because low vegetation casts hardly any shadow. (ii) We select all pixels with a height between 2 and $5 \mathrm{~m}$, convert them into a spatial polygon and calculate the shadow for an object of that shape and a height of $2 \mathrm{~m}$. (iii) We repeat step (ii) with all pixels with a height between 5 and $8 \mathrm{~m}, 8$ and $11 \mathrm{~m}$, and so forth, until the maximum height of the vegetation in the garden is reached. We choose intervals of $3 \mathrm{~m}$, because the calculation takes quite a while and a higher resolution would have slowed down the app. In a final step, the individual shadows are dissolved, and the final area is calculated. Of course, this is a very simplified representation of trees. In order to reduce errors from simplification, we have chosen the shading for a day when the sun is at its highest (22 June, 12:00), i.e., when the sunrays hit the vegetation from above rather than from the side. For scaling the output barplot in the app, we compare the shadow area with the garden area. No shadow is considered the worst, though a shadow covering more than $110 \%$ is considered best (see also Video S3).

\subsubsection{Biodiversity Assessment}

Biodiversity potential is calculated according to 'Model 1' by [50]:

$$
S_{\text {actual }}=4.74+0.08 * S_{\text {reported }}+0.17 * H_{\text {reported }} \text {, }
$$

where actual plant species richness is $S_{\text {actual, }}$ reported plant species richness according to the questionnaire is $S_{\text {reported, }}$, and reported habitat variability is $H_{\text {reported. Maximum biodiversity potential }}$ is reached when lawn, meadow, flower and vegetable patches are marked at highest diversity levels (maximum value of $S_{\text {reported }}$ is 3) and all checkboxes referring to additive elements in the garden are checked and shrubs and trees are found in the garden (the maximum value of $H_{\text {reported }}$ is 12). Since a particular value of actual plant species richness is difficult to interpret for the gardeners, we decided to present the biodiversity potential of the garden as proportional output: the minimum biodiversity 
potential (or $0 \%$ ) equals the intercept of the above given formula and the maximum (or $100 \%$ ) equals a value of 7.74, which is the maximum value that can be reached (see also Video S3).

\subsubsection{Connectivity, Report and Option for Uploading Input}

In this panel, the gardeners are presented with maps of the current densities for squirrels and hedgehogs from Section 2.3. so that they can explore whether their garden is potentially important for habitat connectivity of the two species. Below the panel, gardeners can download their personal garden report as a PDF and they can decide whether they want to store their input in the database (see also Video S3).

\section{Results}

Since 2016, we collected 75 gardens and backyards during five public events in: 'TU Night' (open day of the Technische Universität Braunschweig) in 2016, 2018 and 2019, 'Langer Tag der StadtNatur' (day of urban nature) in 2018, 'Aktionstag Natur zum Anfassen' (nature action day) in 2019. The garden areas range between 24 and $7060 \mathrm{~m}^{2}$, with a median of $405 \mathrm{~m}^{2}(\mathrm{~N}=75$; Figure 4). In 2019, we updated the questionnaire for the biodiversity assessment, and so the following results on gardens refer to the 26 gardens we collected since then. While more than half of the gardens provided nesting boxes and food for birds, deadwood and wild patches, open compost, nesting sites for wild bees, unclipped hedges and berry patches, 10 gardens provided drywalls and only four gardens provided ponds (Figure 5). In total, 17 gardeners checked the most diverse image for flower patches in the questionnaire. Only half of the gardens were used for growing vegetables $(\mathrm{N}=14)$. Slightly more than one-third of the gardens provided meadow patches $(\mathrm{N}=10)$. Four gardeners stated that they did not have a lawn or vegetable patches, but meadow and flower patches instead. Gardeners reached $36 \%-87 \%$ (median of $72 \%$ ) of the potential maximum for biodiversity support in their gardens (Figure 6).

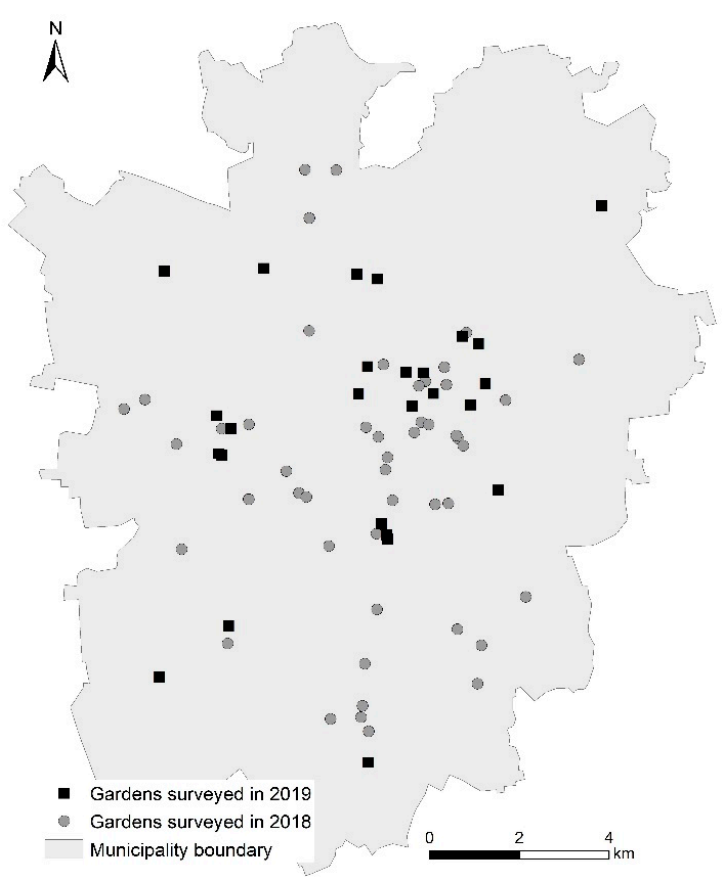

Figure 4. Locations of 75 gardens collected during several public events between 2016 and 2019. Black squares are gardens collected in 2019 after updating the questionnaire for the biodiversity assessment. 


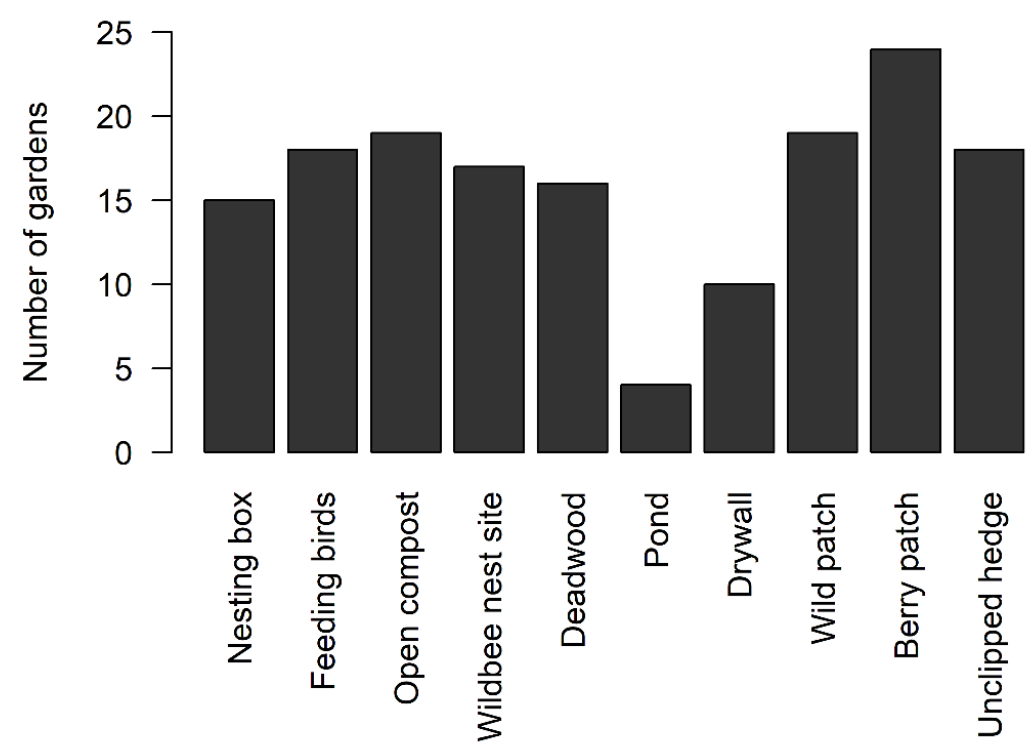

Figure 5. Presence of features that enhance the biodiversity potential of gardens for 26 gardens collected during three public events in 2019.

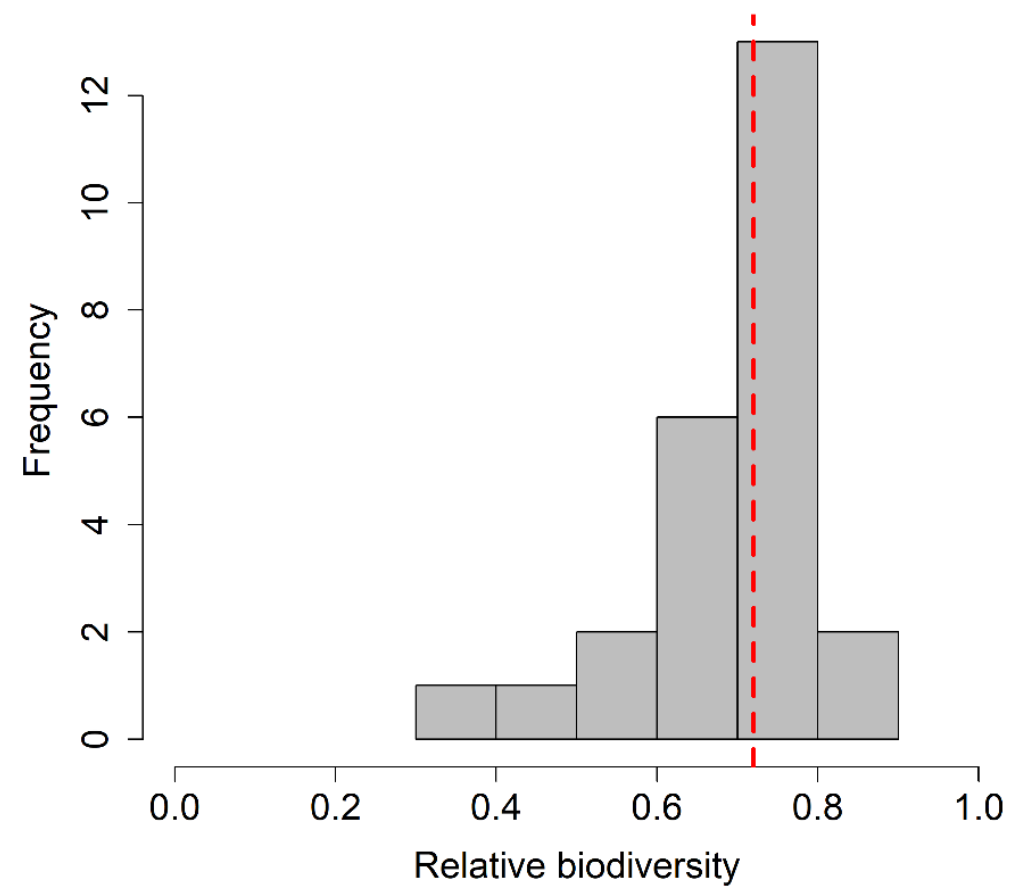

Figure 6. Relative biodiversity for 26 gardens collected during three public events in 2019. Maximum is reached when all checkboxes in the biodiversity questionnaire are checked and lawn, meadow, flower and vegetable patches are marked at highest diversity levels. The dashed line shows the median of relative biodiversity.

The comparison of gardener's observations of squirrels and hedgehogs $(\mathrm{N}=75)$ with current densities showed no significant results. In the case of squirrels, the median of maximum current densities from the connectivity model was lower for absence statements than for presence statements (Figure 7a), but according to a Wilcoxon rank sum test, the effect is non-significant $(\mathrm{W}=425, \mathrm{P}=0.19)$. For the hedgehogs, the median of maximum current densities from the connectivity model was also lower for absence statements than for presence statements, but again, the difference was not significant $(\mathrm{W}=420.5, \mathrm{p}$-value $=0.36$; Figure $7 \mathrm{~b})$. 
a) Squirrels

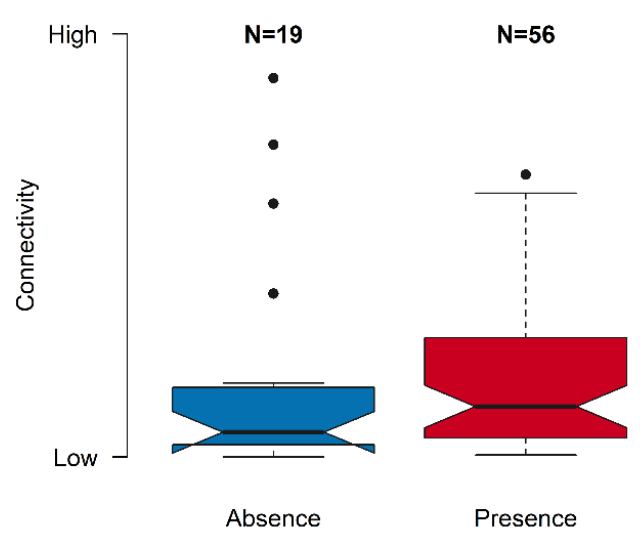

b) Hedgehogs

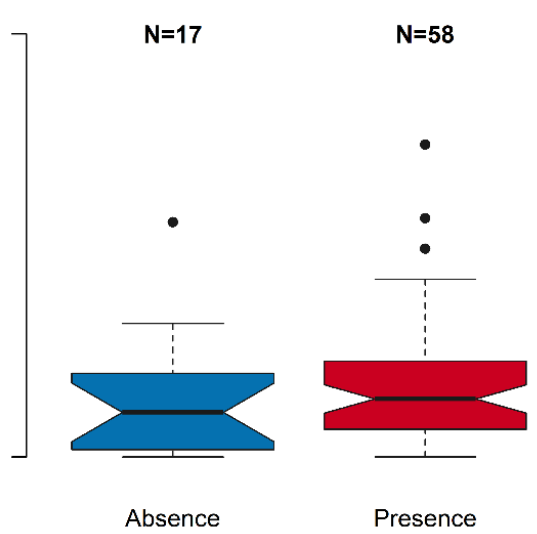

Figure 7. Maximum current density from the 75 gardens according to the connectivity models for (a) squirrels and (b) hedgehogs related to gardeners' observations of the presence/absence of these species in their gardens. Current flow density is given as relative connectivity ranging between low and high, since real values are not comparable.

\section{Discussion}

The GartenApp is a successful combination of what [31] is described as 'technology data' (i.e., remote sensing material) and 'in situ data' derived from citizen science surveys. Thus, the app could serve as a communication tool between scientists, citizens and municipalities. There are many potential additions to the app. The most evident one is to encourage friendly competition between gardeners for yielding the 'best garden or quarter' in terms of ecosystem services, biodiversity and connectivity. Other additions could focus on invasive plants or biocontrol, connectivity models for other species, or machine learning technologies for species recognitions. It is important, however, not to overburden the app, because of the potentially negative impacts on the user experience [69].

In order to be meaningful for gardeners, the quality of content is important. In our case, the LiDAR data is quite old, and we were frequently told during public events that changes have occurred since then. While remote sensing material is frequently updated in Germany, availability can be quite problematic. The quality of the connectivity models has not fully been assessed, because there are no systematic surveys of squirrels and hedgehogs in Braunschweig. A comparison with hedgehog observations from a citizen science project by the conservation non-profit organization 'Bund für Umwelt und Naturschutz Deutschland-BUND e.V.' has shown that current densities are significantly higher than at randomly chosen locations [70]. The comparison of current densities for gardens assessed with the GartenApp, showed no significant differences for observations of squirrels and hedgehogs, however. We can only speculate, but we would assume that people may not have observed the nocturnal hedgehogs in their gardens, even though they are present. With squirrels, the difference between gardens with and without observations is more pronounced, probably because they are clearly identifiable during the day and false negatives are unlikely. The availability of resources is not captured in the model, however, and, for example, a single hazelnut tree could lead to squirrel 'traffic' that the model would overlook. In any case, for improved connectivity models, systematic observations and tracking data would be needed [14]. Nevertheless, we consider the quality sufficient for illustrating the general role of the garden in the GI of Braunschweig. The computation of the models took several days. So, larger cities may have to reduce the spatial resolution. While the data on the server is quite large (in our case $34 \mathrm{~GB}$ ), it does not affect the usability of the app, because only the data for the selected polygon and its vicinity are downloaded and processed.

There are also uncertainties linked to the ecosystem service and biodiversity assessment. The carbon storage calculation is rather simplistic and based on multiplying a factor to canopy cover, ignoring heights. While cooling is based on measurements from Braunschweig, it ignores 
the wider surrounding and features such as waterbodies or buildings. The shading by vegetation is important but may be dwarfed by the shading from buildings. For the current purpose of the app, these issues are of minor importance, however, because the main output are bar graphs with relative values on a scale from 'low' to 'high'.

We consider the selection of ecosystem services and modelled species to be quite representative for central and western Europe. If orthophotos, LiDAR data and detailed land-use maps are available, the app can easily be adapted. The role of gardens for stormwater management and retention is something that we would like to explore in the future. For other parts of the world, other ecosystem services and species may be more relevant. In Phoenix (Arizona, USA), for instance, issues related to water conservation are extremely important $[29,71]$. Since the GartenApp is a flexible platform rather than a static software, it can be adapted to such needs.

The results gathered with the GartenApp thus far should be interpreted with care. While they cover many parts of the city (Figure 4), the sample size is small and the kind of people who visit a 'day of urban nature' or an info booth on urban nature at the open day of the University are probably not very representative of average gardeners. This would also explain why so many biodiversity enhancing features are present (Figures 5 and 6). Thus, in a next step, the effectiveness of the GartenApp in serving as a communication tool between scientists, citizens and municipalities that can reach a wider audience and induce real-world changes should be tested. We do not expect the app to be a stand-alone tool, because, after all, direct human interaction in local communities and real-world examples are essential for change and stewardship [24,72-74], and raising awareness and appealing to values may not be enough to encourage changes in gardeners [25,71]. Of the five stimulating levers of a toolbox for garden governance described by [24], two could be supported by the GartenApp. The first lever, 'enable,' includes providing and sharing information in a simple, correct, orderly and accessible fashion. In that line, the GartenApp could enable and nudge citizens into changing garden design and management, e.g., by demonstrating how this contributes to biodiversity conservation, ecosystem service provision, or both. In fact, a common request by users was to see how their garden compares to others. Another lever, 'explore,' includes collecting data on domestic gardens for analyzing success or failures. In the GartenApp, we have started exploring the quality of the connectivity models with information provided by the gardeners.

\section{Conclusions}

Gardens make up large quantities of UGSs and cities cannot afford to ignore this resource. Here, we have introduced an innovative web application that makes state-of-the-art research directly available to citizens and, at the same time, allows them to contribute their local knowledge. It is based on open-source software and can be adapted to local needs. From our own experience, but also considering the literature, the GartenApp will, however, not have a big impact as a standalone tool. Instead, we view the GartenApp as a building block for the governance of gardens to overcome the 'Tyranny of Small Decisions.'

Supplementary Materials: The following are available online at http://www.mdpi.com/2071-1050/12/1/95/s1. Video S1: The app in action part 1; Video S2: The app in action part 2; Video S3: The app in action part 3.

Author Contributions: Conceptualization, A.-K.S. and M.W.S.; Writing-Original Draft, A.-K.S. and M.W.S.; Formal analysis A.-K.S., M.W.S. and M.A.; Software A.-K.S. and M.W.S.; Writing-Review and Editing, A.-K.S., M.W.S., M.A. and B.S.; Funding acquisition, B.S. All authors have read and agreed to the published version of the manuscript.

Funding: This research was funded by the program 'Science for Sustainable Development' of the Volkswagen Foundation and the Ministry for Science and Culture of Lower Saxony (mETAPolis, grant No. ZN3121).

Acknowledgments: We thank the city of Braunschweig and the Regionalverband Braunschweig for providing geodata. Thanks to Andreas Dahlkamp who contributed to an early version of the GartenApp and to Julian Jentsch for setting up the servers and for technical support.

Conflicts of Interest: The authors declare no conflict of interest. 


\section{Appendix A}

Table A1. The landscape resistance values used for the Circuitscape modelling of squirrels, based on resistance set 'R26' from [45].

\begin{tabular}{cc}
\hline Description & Resistance \\
\hline Buildings & No Data \\
Water & 1000 \\
Agricultural land & 800 \\
Railway, roads, impervious surfaces & 800 \\
Trees & 1 \\
Shrubs & 10 \\
Grass layer & 100 \\
\hline
\end{tabular}

Table A2. The landscape resistance values used for the Circuitscape modelling of hedgehogs, based on resistances from [46].

\begin{tabular}{cc}
\hline Description & Resistance \\
\hline Gardens & 1 \\
Pasture & 1 \\
Public green areas & 1 \\
Allotment gardens & 1 \\
Cemeteries & 1 \\
Deciduous forest & 3 \\
Grove & 3 \\
Sports area & 5 \\
Airfield & 5 \\
Ruderal & 6 \\
Small streets & 8 \\
Impervious & 14 \\
Paths & 16 \\
Squares & 16 \\
Opencast mining & 39 \\
Mixed Forest & 50 \\
Tram & 100 \\
Swamp & 100 \\
Highways & 100 \\
Railway & 100 \\
Coniferous forest & 100 \\
Big streets & 100 \\
Waterbodies & 100 \\
Arable land & 100 \\
Buildings & No Data \\
Canal & No Data \\
\hline
\end{tabular}

\section{References}

1. Strohbach, M.W.; Haase, D. Above-ground carbon storage by urban trees in Leipzig, Germany: Analysis of patterns in a European city. Landsc. Urban Plan. 2012, 104, 95-104. [CrossRef]

2. Gill, S.E.; Handley, J.F.; Ennos, A.R.; Pauleit, S. Adapting cities for climate change: The role of the Green Infrastructure. Built Environ. 2007, 33, 115-133. [CrossRef]

3. Ziter, C.D.; Pedersen, E.J.; Kucharik, C.J.; Turner, M.G. Scale-dependent interactions between tree canopy cover and impervious surfaces reduce daytime urban heat during summer. Proc. Natl. Acad. Sci. USA 2019, 116, 7575-7580. [CrossRef] [PubMed]

4. Maragno, D.; Gaglio, M.; Robbi, M.; Appiotti, F.; Fano, E.; Gissi, E. Fine-scale analysis of urban flooding reduction from green infrastructure: An ecosystem services approach for the management of water flows. Ecol. Model. 2018, 386, 1-10. [CrossRef] 
5. Brown, G.; Schebella, M.F.; Weber, D. Using participatory GIS to measure physical activity and urban park benefits. Landsc. Urban Plan. 2014, 121, 34-44. [CrossRef]

6. Hartig, T.; Kahn, P.H. Living in cities, naturally. Science 2016, 352, 938-940. [CrossRef]

7. Dunn, R.R.; Gavin, M.C.; Sanchez, M.C.; Solomon, J.N. The Pigeon Paradox: Dependence of Global Conservation on Urban Nature. Conserv. Biol. 2006, 20, 1814-1816. [CrossRef]

8. Davis, A.M.; Glick, T.F. Urban Ecosystems and Island Biogeography. Environ. Conserv. 1978, 5, $299-304$. [CrossRef]

9. Shanahan, D.F.; Strohbach, M.W.; Warren, P.S.; Fuller, R.A. The Challenges of Urban Living; Oxford University Press: Oxford, UK, 2014.

10. Strohbach, M.W.; Arnold, E.; Haase, D. The carbon footprint of urban green space-A life cycle approach. Landsc. Urban Plan. 2012, 104, 220-229. [CrossRef]

11. Belaire, J.A.; Whelan, C.J.; Minor, E.S. Having our yards and sharing them too: The collective effects of yards on native bird species in an urban landscape. Ecol. Appl. 2014, 24, 2132-2143. [CrossRef]

12. Rudd, H.; Vala, J.; Schaefer, V. Importance of backyard habitat in a comprehensive biodiversity conservation strategy: A connectivity analysis of urban green spaces. Restor. Ecol. 2002, 10, 368-375. [CrossRef]

13. Goddard, M.A.; Dougill, A.J.; Benton, T.G. Scaling up from gardens: Biodiversity conservation in urban environments. Trends Ecol. Evol. 2010, 25, 90-98. [CrossRef] [PubMed]

14. Lynch, A.J. Creating Effective Urban Greenways and Stepping-stones: Four Critical Gaps in Habitat Connectivity Planning Research. J. Plan. Lit. 2019, 34, 131-155. [CrossRef]

15. Ahern, J. Green infrastructure for cities: The spatial dimension. In Cities of the Future: Towards Integrated Sustainable Water and Landscape Management; Novotny, V., Brown, P., Eds.; IWA Publishing: London, UK, 2007; pp. 267-283.

16. Gaston, K.J.; Warren, P.H.; Thompson, K.; Smith, R.M. Urban Domestic Gardens (IV): The extent of the resource and its associated features. Biodivers. Conserv. 2005, 14, 3327-3349. [CrossRef]

17. Loram, A.; Tratalos, J.; Warren, P.H.; Gaston, K.J. Urban domestic gardens (X): The extent \& structure of the resource in five major cities. Landsc. Ecol. 2007, 22, 601-615. [CrossRef]

18. Cameron, R.; Blanuša, T.; Taylor, J.E.; Salisbury, A.; Halstead, A.J.; Henricot, B.; Thompson, K. The domestic garden-Its contribution to urban green infrastructure. Urban For. Urban Green. 2012, 11, 129-137. [CrossRef]

19. Cook, E.M.; Hall, S.J.; Larson, K.L. Residential landscapes as social-ecological systems: A synthesis of multi-scalar interactions between people and their home environment. Urban Ecosyst. 2012, 15, $19-52$. [CrossRef]

20. Lepczyk, C.A.; Aronson, M.F.J.; Evans, K.L.; Goddard, M.A.; Lerman, S.B.; MacIvor, J.S. Biodiversity in the city: Fundamental questions for understanding the ecology of urban green spaces for biodiversity conservation. BioScience 2017, 67, 799-807. [CrossRef]

21. Casalegno, S.; Anderson, K.; Cox, D.T.; Hancock, S.; Gaston, K.J. Ecological connectivity in the three-dimensional urban green volume using waveform airborne lidar. Sci. Rep. 2017, 7, 45571. [CrossRef]

22. Aronson, M.F.J.; Lepczyk, C.A.; Evans, K.L.; Goddard, M.A.; Lerman, S.B.; MacIvor, S.J.; Nilon, C.H.; Vargo, T. Biodiversity in the city: Key challenges for urban green space management. Front. Ecol. Environ. 2017, 15, 189-196. [CrossRef]

23. Odum, W.E. Environmental Degradation and the Tyranny of Small Decisions. BioScience 1982, 32, 728-729. [CrossRef]

24. Dewaelheyns, V.; Kerselaers, E.; Rogge, E. A toolbox for garden governance. Land Use Policy 2016, 51, $191-205$. [CrossRef]

25. Beumer, C. Show me your garden and I will tell you how sustainable you are: Dutch citizens' perspectives on conserving biodiversity and promoting a sustainable urban living environment through domestic gardening. Urban For. Urban Green. 2018, 30, 260-279. [CrossRef]

26. DG 11 Synthesis Report 2018: Tracking Progress Towards Inclusive, Safe, Resilient and Sustainable Cities and Human Settlements; Nairobi, Kenya, 2018; Available online: https://sustainabledevelopment.un.org/sdg11 (accessed on 5 December 2019).

27. UN. New Urban Agenda; Habitat III Secretariat: Quito, Ecuador, 2017; Available online: http://habitat3.org/ the-new-urban-agenda (accessed on 5 December 2019).

28. Goddard, M.A.; Dougill, A.J.; Benton, T.G. Why garden for wildlife? Social and ecological drivers, motivations and barriers for biodiversity management in residential landscapes. Ecol. Econ. 2013, 86, 258-273. [CrossRef] 
29. Beumer, C.; Martens, P. BIMBY's first steps: A pilot study on the contribution of residential front-yards in Phoenix and Maastricht to biodiversity, ecosystem services and urban sustainability. Urban Ecosyst. 2016, 19, 45-76. [CrossRef]

30. Beumer, C.; Martens, P. Biodiversity in my (back) yard: Towards a framework for citizen engagement in exploring biodiversity and ecosystem services in residential gardens. Sustain. Sci. 2015, 10, 87-100. [CrossRef]

31. Dobbs, C.; Hernández, A.; de la Barrera, F.; Miranda, M.D.; Paecke, S.R. Integrating urban biodiversity mapping, citizen science and technology. In Urban Biodiversity: From Research to Practice; Ossola, A., Niemelä, J., Eds.; Routledge: London, UK; New York, NY, USA, 2018; pp. 236-247.

32. Verbeeck, K.; Orshoven, J.V.; Hermy, M. Measuring extent, location and change of imperviousness in urban domestic gardens in collective housing projects. Landsc. Urban Plan. 2011, 100, 57-66. [CrossRef]

33. Grafius, D.R.; Corstanje, R.; Siriwardena, G.M.; Plummer, K.E.; Harris, J.A. A bird's eye view: Using circuit theory to study urban landscape connectivity for birds. Landsc. Ecol. 2017, 32, 1771-1787. [CrossRef]

34. Bjerke, T.; Østdahl, T. Animal-related attitudes and activities in an urban population. Anthrozoös 2004, 17, 109-129. [CrossRef]

35. LSN. LSN-Online-die Kostenfreie Regionaldatenbank für Niedersachsen. Available online: https://www1. nls.niedersachsen.de (accessed on 5 August 2019).

36. DWD. Klimadaten Deutschland: Vieljährige Mittelwerte; Deutschen Wetterdienst: Offenbach am Main, Germany, 2019; Available online: https://www.dwd.de/DE/leistungen/klimadatendeutschland/vielj_mittelwerte.html (accessed on 30 October 2019).

37. Kottek, M.; Grieser, J.; Beck, C.; Rudolf, B.; Rubel, F. World Map of the Köppen-Geiger climate classification updated. Meteorol. Z. 2006, 15, 259-263. [CrossRef]

38. Drachenfels, O.v. Überarbeitung der Naturräumlichen Regionen Niedersachsens. Inf. Nat. Niedersachs. 2010, 4, 249-252.

39. LGLN. Auszug aus den Geobasisdaten der Niedersächsischen Vermessungs und Katasterverwaltung; Landesamt für Geoinformation und Landesvermessung Niedersachsen: Hannover, Germany, 2016.

40. BKG. GeoBasis-DE. Available online: https://www.bkg.bund.de/ (accessed on 30 October 2019).

41. Liaw, A.; Wiener, M. Classification and Regression by randomForest. R News 2002, 2, 18-22.

42. R Core Team. R: A language and Environment for Statistical Computing; R Foundation for Statistical Computing: Vienna, Austria, 2018.

43. LGLN. Hausumringe; Landesamt für Geoinformation und Landesvermessung Niedersachsen: Hannover, Germany, 2016.

44. McRae, B.H.; Dickson, B.G.; Keitt, T.H.; Shah, V.B. Using circuit theory to model connectivity in ecology, evolution, and conservation. Ecology 2008, 89, 2712-2724. [CrossRef] [PubMed]

45. Verbeylen, G.; De Bruyn, L.; Adriaensen, F.; Matthysen, E. Does matrix resistance influence Red squirrel (Sciurus vulgaris L. 1758) distribution in an urban landscape? Landsc. Ecol. 2003, 18, 791-805. [CrossRef]

46. Braaker, S.; Moretti, M.; Boesch, R.; Ghazoul, J.; Obrist, M.K.; Bontadina, F. Assessing habitat connectivity for ground-dwelling animals in an urban environment. Ecol. Appl. 2014, 24, 1583-1595. [CrossRef]

47. Chang, W.; Cheng, J.; Allaire, J.J.; Xie, Y.; McPherson, J. Shiny: Web Application Framework for R. 2018. Available online: https://rdrr.io/cran/shiny/ (accessed on 20 December 2019).

48. Cheng, J.; Karambelkar, B.; Xie, Y. Leaflet: Create Interactive Web Maps with the JavaScript 'Leaflet' Library. 2018. Available online: https://www.igismap.com/leaflet-getting-started-to-create-map-application/ (accessed on 20 December 2019).

49. Bucklin, D.; Basille, M. Rpostgis: Linking R with a PostGIS spatial database. R J. 2018, 10, 251-268. [CrossRef]

50. Young, C.; Frey, D.; Moretti, M.; Bauer, N. Research Note: Garden-owner reported habitat heterogeneity predicts plant species richness in urban gardens. Landsc. Urban Plan. 2019, 185, 222-227. [CrossRef]

51. Osborne, J.L.; Martin, A.P.; Shortall, C.R.; Todd, A.D.; Goulson, D.; Knight, M.E.; Hale, R.J.; Sanderson, R.A. Quantifying and comparing bumblebee nest densities in gardens and countryside habitats. J. Appl. Ecol. 2007, 45, 784-792. [CrossRef]

52. Fuller, R.A.; Warren, P.H.; Armsworth, P.R.; Barbosa, O.; Gaston, K.J. Garden bird feeding predicts the structure of urban avian assemblages. Divers. Distrib. 2008, 14, 131-137. [CrossRef]

53. Daniels, G.D.; Kirkpatrick, J.B. Does variation in garden characteristics influence the conservation of birds in suburbia? Biol. Conserv. 2006, 133, 326-335. [CrossRef] 
54. Chamberlain, D.E.; Cannon, A.R.; Toms, M.P. Associations of garden birds with gradients in garden habitat and local habitat. Ecography 2004, 27, 589-600. [CrossRef]

55. Smith, R.M.; Gaston, K.J.; Warren, P.H.; Thompson, K. Urban domestic gardens (VIII): Environmental correlates of invertebrate abundance. Biodivers. Conserv. 2006, 15, 2515-2545. [CrossRef]

56. Ødegaard, F.; Tømmerås, B.Å. Compost heaps-Refuges and stepping-stones for alien arthropod species in northern Europe. Divers. Distrib. 2000, 6, 45-59. [CrossRef]

57. Gaston, K.J.; Smith, R.M.; Thompson, K.; Warren, P.H. Urban domestic gardens (II): Experimental tests of methods for increasing biodiversity. Biodivers. Conserv. 2005, 14, 395-413. [CrossRef]

58. Thompson, P.S.; Greenwood, J.J.D.; Greenaway, K. Birds in European gardens in the winter and spring of 1988-89. Bird Study 1993, 40, 120-134. [CrossRef]

59. Forman, R.T.T. Urban Ecology; Cambridge University Press: Cambridge, UK, 2013.

60. Sirohi, M.H.; Jackson, J.; Edwards, M.; Ollerton, J. Diversity and abundance of solitary and primitively eusocial bees in an urban centre: A case study from Northampton (England). J. Insect Conserv. 2015, 19, 487-500. [CrossRef]

61. Fortel, L.; Henry, M.; Guilbaud, L.; Mouret, H.; Vaissière, B.E. Use of human-made nesting structures by wild bees in an urban environment. J. Insect Conserv. 2016, 20, 239-253. [CrossRef]

62. Hof, A.R.; Bright, P.W. The value of agri-environment schemes for macro-invertebrate feeders: Hedgehogs on arable farms in Britain. Anim. Conserv. 2010, 13, 467-473. [CrossRef]

63. Loram, A.; Warren, P.; Thompson, K.; Gaston, K. Urban domestic gardens: The effects of human interventions on garden composition. Environ. Manag. 2011, 48, 808-824. [CrossRef]

64. Reis, C.; Lopes, A. Evaluating the cooling potential of urban green spaces to tackle urban climate change in Lisbon. Sustainability 2019, 11, 2480. [CrossRef]

65. Grunwald, L.; Kossmann, M.; Weber, S. Mapping urban cold-air paths in a Central European city using numerical modelling and geospatial analysis. Urban Clim. 2019, 29, 100503. [CrossRef]

66. Pinheiro, J.; Bates, D.; DebRoy, S.; Sarkar, D. nlme: Linear and Nonlinear Mixed Effects Models. 2018. Available online: https://cran.r-project.org/web/packages/nlme/nlme.pdf (accessed on 20 December 2019).

67. Lindberg, F.; Grimmond, C.S.B. Nature of vegetation and building morphology characteristics across a city: Influence on shadow patterns and mean radiant temperatures in London. Urban Ecosyst. 2011, 14, 617-634. [CrossRef]

68. Dorman, M. Shadow: Geometric Shadow Calculations. R Package Version 0.6.0. 2019. Available online: https://github.com/michaeldorman/shadow (accessed on 20 December 2019).

69. Sturm, U.; Schade, S.; Ceccaroni, L.; Gold, M.; Kyba, C.; Claramunt, B.; Haklay, M.; Kasperowski, D.; Albert, A.; Piera, J.; et al. Defining principles for mobile apps and platforms development in citizen science. Res. Ideas Outcomes 2017, 3. [CrossRef]

70. App, M. Der Effekt von Stadtgrün auf Landschaftliche Konnektivität für Igel (Erinaceus europaeus): Ein Ansatz über die Circuit Theory. Master's Thesis, Technische Universität Braunschweig, Braunschweig, Germany, 2019.

71. Larson, K.L.; Cook, E.; Strawhacker, C.; Hall, S.J. The Influence of Diverse Values, Ecological Structure, and Geographic Context on Residents' Multifaceted Landscaping Decisions. Hum. Ecol. 2010, 38, 747-761. [CrossRef]

72. Andersson, E.; Barthel, S.; Borgström, S.; Colding, J.; Elmqvist, T.; Folke, C.; Gren, Å. Reconnecting cities to the biosphere: Stewardship of Green Infrastructure and urban ecosystem services. AMBIO 2014, 43, 445-453. [CrossRef]

73. Hunter, M.C.R.; Brown, D.G. Spatial contagion: Gardening along the street in residential neighborhoods. Landsc. Urban Plan. 2012, 105, 407-416. [CrossRef]

74. Diduck, A.P.; Raymond, C.M.; Rodela, R.; Moquin, R.; Boerchers, M. Pathways of learning about biodiversity and sustainability in private urban gardens. J. Environ. Plan. Manag. 2019. [CrossRef]

(C) 2019 by the authors. Licensee MDPI, Basel, Switzerland. This article is an open access article distributed under the terms and conditions of the Creative Commons Attribution (CC BY) license (http://creativecommons.org/licenses/by/4.0/). 